Fikrah: Jurnal Ilmu Aqidah dan Studi Keagamaan

ISSN 2354-6147 EISSN 2476-9649

Tersedia online di: journal.stainkudus.ac.id/index.php/fikrah

DOI: 10.21043/fikrah.v6i1.3536

\title{
Pengobatan Dukun Prewangan Ditinjau dari Akidah Islamiyah: Analisa Kepercayaan Masyarakat Desa Ngelokulon Kecamatan Mijen Kabupaten Demak
}

\author{
Khusniatul Farida Rianissani \\ Institut Agama Islam Negeri Kudus, Indonesia \\ khusniatulfarida@gmail.com
}

\begin{abstract}
Abstrak
Artikel ini membahas tentang kepercayaan masyarakat pada pengobatan dukun prewangan di Desa Ngelokulon. Observasi dan interview dilakukan untuk mendapatkan data. Pendekatan fenomenologi digunakan untuk menganalisis data. Hasil yang didapat menunjukkan bahwa masyarakat masih mempercayai pengobatan dukun prewangan meskipun itu dilarang dalam ajaran agama yang mereka anut. Kepercayaan masyarakat pada pengobatan dukun prewangan disebabkan oleh beberapa faktor yaitu letak rumah dukun yang dekat yaitu berada dalam satu desa. Kedua, tersebarnya informasi keefektifan pengobatan dukun dari orang lain. Ketiga, upah yang relatif murah. Keempat, kurangnya pengetahuan masyarakat tentang pengobatan yang sesuai syariat Islam. Kelima, rasa penasaran dan ingin mencoba pengobatan dukun prewangan atas informasi dan pengalaman orang lain. Pentingnya artikel ini adalah untuk mengungkapkan bahwa praktik perdukunan masih tetap eksis ditengah modernitas dan perubahan zaman. Fenomena ini merupakan warisan leluhur yang masih tetap bertahan.

Katakunci: Kepercayaan masyarakat, pengobatan tradisional, dukun prewangan, akidah Islamiyah, fenomenologi
\end{abstract}




\begin{abstract}
This article discusses the public trust in prewangan shaman treatment in Ngelokulon Village. Observations and interviews were conducted to obtain data. The phenomenology approach is used to analyze data. The results of this study indicate that the community still believes in prewangan dukun treatment even though it is prohibited in the teachings of their religion. Community trust in the treatment of prewangan herbalists is caused by several factors, namely the location of a shaman's house that is close to being in one village. Secondly, the information on the effectiveness of dukun treatment from others is spread. Third, relatively low wages. Fourth, the lack of public knowledge about treatment that is in accordance with Islamic law. Fifth, feel curious and want to try the prewangan shaman treatment for information and experiences of others. The importance of this article is to reveal that the practice of shamanism still exists amid modernity and changing times. This phenomenon is an ancestral heritage that still persists.
\end{abstract}

Keywords: Peoples faith, traditional medicine, the prewangan shaman, Islamic faith, phenomenology

\title{
Pendahuluan
}

Masyarakat Jawa saat ini masih kental dengan warisan leluhurnya. Salah satunya adalah praktek pengobatan dukun. Masyarakat masih banyak yang percaya terhadap dukun untuk mengobati anaknya. Meskipun era teknologi dan kemajuan zaman yang semakin pesat berkembang, kepercayaan dan kebudayaan yang dahulu masih bertahan sampai sekarang. Di era zaman modern seperti sekarang ini dengan kemajuan alat dan pemikiran, praktek-praktek perdukunan masih tersebar luas. Biasanya dukun memiliki karakteristik tersendiri dalam pengobatannya. Keseimbangan jumlah pasien antara dokter dan dukun dalam mengobati mencerminkan eksistensinya. Dokter menggunakan alat-alat canggih sedangkan dukun menggunakan alat-alat yang tidak biasa misalnya sesajen, sawanan dan lain-lain. Namun kenyataan bahwa pasien dukun juga banyak, baik dari kalangan kelas ekonomi kebawah sampai kelas atas. Orang yang datang ke dukun bukan berarti mereka yang tidak beragama Islam, seperti halnya masyarakat Desa Ngelokulon yang mayoritas mereka beragama Islam.

Islam adalah agama yang membawa rahmat bagi seluruh alam. Allah menurunkan al-Quran dan hadis sebagai petunjuk bagi umat Islam. Salah satunya adalah masalah penyakit. Menurut Imam Ibnul Qayyim dalam kitab Zaadul Ma'ad (juz 
IV) yang dikenal dengan at-Thibb an-Nabawi (pengobatan Nabi). Nabi bersabda yang artinya:

"Setiap penyakit ada obatnya, maka jika obat telah mengenai penyakit maka akan sembuh dengan izin Allah azza wa jalla." (HR.Muslim) (Utomo, 2003, hal. 234).

Dalam hadis tersebut sudah jelas bahwa penyakit ada obatnya, namun sebagai manusia kita harus berusaha dan berdoa agar Allah menyembuhkan penyakit. Jika Allah mengizinkan menyembuhkan penyakit seseorang maka seberat apapun penyakitnya akan sembuh juga. Karena Allah adalah Sang Maha segala-galanya. Segala penyakit ada obatnya, kecuali satu yaitu tua. Nabi saw. bersabda yang artinya:

"Ya, wahai hamba-hamba Allah, berobatlah karena Allah azza wajalla tidak menaruh penyakit kecuali menaruh padanya obatnya, kecuali satu penyakit yaitu kerentaan." (HR Ahmad).

Niat merupakan hal penting dalam berobat. Karena penyakit datangnya dari Allah, maka dalam berusaha sembuh dari penyakit manusia harus niat berobat karena Allah. Cara berobat, obat-obatan maupun lainnya harus sesuai aturan Allah. Manusia tidak bisa menolak satu penyakit yaitu tua, karena itu adalah takdir yang diberikan Allah. Seorang yang kaya, mempunyai jabatan dan lain-lain tetap saja akan mengalami usia tua. Namun yang dapat manusia lakukan adalah mengatur dan menjaga gaya hidup sehat agar penyakit usia tua tersebut tidak datang terlalu cepat.

Fakta menunjukkan ada orang sakit yang berobat ke dokter menjadi sembuh atau tetap sakit. Kemudian orang yang tidak sembuh berobat ke dukun menjadi sembuh. Adapula orang sakit berobat ke dukun tidak sembuh dan berobat ke dokter menjadi sembuh. Adapula orang yang sakit berobat ke dokter dan dukun namun tetap sakit (Amir, 2009, hal. 153). Banyak masyarakat yang mengalami hal seperti ini, sudah berobat ke dokter namun tidak kunjung sembuh akhirnya jalan lain yang ditempuh adalah pergi ke dukun dan akhirnya sembuh juga. Fakta ini tidak bisa dipungkiri, sebagaimana fenomena pengobatan yang terjadi di masyarakat Desa Ngelokulon.

Ada banyak cara yang ditempuh masyarakat untuk mengobati penyakit, baik dengan berobat ke dokter, berobat alternatif, dukun dan lain sebagainya. Akidah seseorang juga berpengaruh untuk menentukan cara penyembuhan penyakit. 
Pembentuk akidah seseorang menurut Le Bon ada dua macam yaitu pembentuk yang jauh dan yang dekat (Ash-Shiddiqiey, 2009, hal. 34). Pembentuk yang jauh adalah masyarakat menerima beberapa kepercayaan dan menolak beberapa kepercayaan. Misalnya masyarakat ada yang mempercayai dukun sebagai perantara penyembuh penyakit maupun ada juga yang tidak percaya. Sedangkan pembentuk akidah yang dekat adalah sesuatu yang datang setelah melakukan sesuatu. Misalnya sembuh dari penyakit setelah berusaha berobat dengan susah payah dan berdoa. Masyarakat Desa Ngelokulon dalam berusaha menyembuhkan penyakit biasanya mereka berobat ke dokter dan ada pula yang datang ke dukun. Dukun yang dimaksud dalam artikel ini adalah dukun prewangan, yaitu dukun yang kerasukan jin atau makhluk halus.

\section{Metode}

Jenis artikel ini merupakan artikel kualitatif yang mendeskripsikan dan menganalisis fenomena kepercayaan masyarakat desa Ngelokulon pada pengobatan dukun prewangan dengan menggunakan pendekatan fenomenologi. Peneliti memilih pendekatan fenomenologi untuk memaparkan makna pengalaman individu yang memiliki kecenderungan percaya pada pengobatan dukun prewangan. Pendekatan fenomenologi juga digunakan untuk mengungkapkan pengalaman hidup atau dari responden untuk dimaknai secara subjektif.

\section{Topografi Desa Ngelokulon}

Desa Ngelokulon adalah salah satu desa di Kecamatan Mijen Kabupaten Demak. Luas wilayah desa ini adalah 277,590 hektar. Letak geografis desa ini di sebelah utara Kabupaten Demak dan berdekatan dengan Kabupaten Jepara. Mata pencaharian warga adalah petani, buruh tani dan buruh lainnya. Luas sawah yang dimiliki desa ini adalah 80\% dari luas wilayah keseluruhan. Jarak tempuh dari desa ke kecamatan adalah 10 menit dengan jarak sejauh $5 \mathrm{~km}$. Kondisi jalan desa sudah bagus dengan material paving. Batas Desa Ngelokulon sebelah utara berbatasan dengan Desa Ngegot, sebelah timur berbatasan dengan Desa Jleper, sebelah selatan berbatasan dengan Desa Turirejo dan sebelah barat berbatasan dengan Desa Pasir. Kondisi demografis Desa Ngelokulon mayoritas berupa lahan sawah. Sawah milik masyarakat sendiri memiliki luas 165,970 hektar, luas tegalan sekitar 30 hektar dan luas lahan "bengkok pamong" sekitar 26,955 
hektar. Jumlah penduduk sekitar 3236 jiwa yang terbagi dalam 1135 kepala keluarga dengan pembagian $10 \mathrm{RT}$ dan $2 \mathrm{RW}$ dan keseluruhan warganya beragama Islam. Desa ini memiliki bangunan tempat ibadah berjumlah 9 bangunan yang terdiri dari 1 masjid dan 8 musholla.

Mata pencaharian masyakat mayoritas petani. Lahan sawah ditanami padi dan bawang merah yang menjadi komoditi utama, sehingga desa ini termasuk salah satu desa penghasil bawang merah di Kecamatan Mijen. Meskipun termasuk desa yang kecil dan memiliki lahan sawah yang luas, kondisi ekonomi masyarakat masih relatif minim. Saat musim panen tiba biasanya harga hasil panen bawang merah relatif murah sehingga petani mengalami kerugian, karena harga bibit bawang merah jauh lebih mahal dibanding harga bawang merah saat panen.

\section{Kondisi Sosial Keagamaan di Desa Ngelokulon}

Masyarakat Desa Ngelokulon mayoritas beragama Islam dan memiliki tempat ibadah yang banyak. Hal ini tentunya sangat menunjang pelaksanaan kegiatan sosial keagamaan yang dilakukan masyarakat, seperti pengajian yang diikuti oleh seluruh kalangan baik anak-anak, ibu-ibu dan bapak-bapak. Setiap hari musholla dan masjid ramai dengan orang yang berjamaah menunaikan shalat, kemudian dilanjutkan dengan kegiatan mengaji al-Quran oleh anak-anak yang dimulai setelah shalat Magrib sampai menjelang shalat Isya'. Tidak hanya itu, kegiatan keagamaan para ibu juga dilakukan setiap minggu dan setiap bulan. Seperti pengajian Jumat siang, Minggu siang, muslimatan dan masih banyak lagi. Kegiatan para bapak juga tidak kalah dengan para ibu, ada pengajian jamiyah perkelompok-kelompok dan masih banyak lagi. Sedangkan kegiatan bersama antara para bapak dan para ibu adalah kegiatan pertemuan tingkat RT. Kegiatan ini dilakukan berbeda-beda setiap RT nya, namun sama-sama dilakukan di rumah warga dengan cara bergilir dan diisi dengan tahlil dan sebagainya. Sehingga rasa solidaritas dan semangat mengikuti kegiatan keagamaan ada dalam diri masyarakat.

\section{Kepercayaan Masyarakat}

Kepercayaan berasal dari kata "percaya", yang berarti mengakui atau meyakini suatu kebenaran. Kepercayaan dapat dimaknai sebagai hal-hal yang berkaitan dengan 
pengakuan atau keyakinan tentang kebenaran. Sumber dari kepercayaan adalah kebenaran. Dalam kehidupan manusia dikenal berbagai macam kepercayaan, yaitu kepercayaan kepada diri sendiri, kepercayaan kepada orang lain, kepercayaan kepada pemerintah atau Negara dan kepercayaan kepada Tuhan. Masing-masing kepercayaan memiliki sistem kepercayaan yaitu fetishisme, yaitu percaya bahwa benda-benda tertentu mempunyai kekuatan atau jiwa, seperti jimat. Animisme, yaitu percaya pada roh-roh yang ada di sekeliling manusia. Animatisme, yaitu percaya bahwa benda dan tumbuhan memiliki jiwa dan dapat berfikir seperti manusia. Dinamisme, yaitu percaya pada kekuatan gaib yang ada dalam segala hal yang luar biasa. Totemisme, yaitu percaya bahwa nenek moyang saling berhubungan kerabat. Politheisme, yaitu kepercayaan pada dewa-dewa. Monotheisme, percaya pada satu Tuhan. Mistik, kepercayaan pada satu dewa atau Tuhan yang dianggap meliputi segala sesuatu di alam (Sujarwa, 1999, hal. 137-142).

\section{Pengobatan Dukun Prewangan di Desa Ngelokulon}

Setiap orang yang sakit pasti memilih pengobatan yang efektif untuk dapat sembuh. Sedangkan pengobatan sendiri adalah usaha seseorang untuk sembuh dari penyakit. Biasanya pengobatan dilakukan oleh orang yang ahli dalam menanganinya, seperti tenaga medis (dokter) atau non medis (dukun). Dokter dan dukun adalah dua profesi yang sangat dikenal masyarakat. Keduanya adalah pekerja sosial yang membantu seseorang sembuh dari penyakitnya dengan caranya masing-masing (Artaria, 2016, hal. 45). Sedangkan usaha untuk mendapatkan kesembuhan dalam bahasa Arab biasa disebut at-tadawi yang artinya menggunakan obat. At-tadawi berasal dari kata dawa yang dalam bahasa Indonesia berarti obat yaitu segala sesuatu yang digunakan manusia untuk menghilangkan atau menyembuhkan penyakit yang diderita (Sayuti, 2013, hal. $40)$.

Dukun juga disebut kahanah, menurut Al-Hafizh Ibnu Hajar, ramalan perdukunan (al-kahanah) adalah mengaku mengetahui perkara gaib, seperti memberitahukan apa yang akan terjadi di bumi (Qardhawy, 1998, hal. 183). Dukun juga mempunyai definisi lain yaitu orang yang mempraktekkan pengetahuannya dalam bidang perdukunan atau orang yang pekerjaannya mengobati, memberi guna-guna dan 
lain sebagainya (Prawirohardjo, 1978, hal. 124-125). Seorang dukun berfungsi sebagai perantara untuk berhubungan dengan makhluk gaib guna mencapai tujuan tertentu atau yang diinginkan (Melalatoa, 1995, hal. 708) Karena dalam prakteknya dukun mengobati pasien melalui makhluk gaib, khususnya pada dukun prewangan dan dukun tiban. Dukun-dukun seperti ini tidak susah untuk diketahui meskipun jumlahnya tidak sebanyak dukun pijat, dukun bayi dan lainnya.

Menurut Geertz (1983, hal. 116) ada beberapa macam dukun yaitu dukun bayi, dukun pijet, dukun prewangan, dukun calak (tukang sunat), dukun wiwit, yaitu dukun yang ahli upacara panen, dukun temanten atau ahli upacara perkawinan, dukun petungan (ahli meramal dengan angka), dukun sihir atau juru sihir, dukun susuk (spesialis mengobati dengan menusukkan jarum emas di bawah kulit), dukun japa (tabib yang mengandalkan mantra), dukun jampi (tabib yang menggunakan tumbuhtumbuhan dan berbagai obat asli), dukun siwer spesialis dalam mencegah kesialan alami (mencegah hujan ketika orang mengadakan pesta besar, mencegah piring agar tidak pecah saat pesta dan sebagainya) dan dukun tiban (tabib yang kekuatannya temporer dan merupakan hasil dari kerasukan roh) (Geertz, 1983).

Dukun-dukun tersebut biasanya tersebar luas di berbagai daerah dan keberadaannya mudah untuk diketahui. Dukun yang banyak ditemukan biasanya adalah dukun bayi karena setiap desa pasti ada dukun bayi. Dukun-dukun biasanya banyak ditemui di desa karena masyarakat banyak yang percaya pada dukun dan masih banyak yang mempelajari ilmu perdukunan. Sedangkan masyarakat perkotaan biasanya lebih mengedepankan ilmu pengetahuan. Namun tidak sedikit pula masyarakat perkotaan yang datang ke dukun yang ada di desa untuk berobat ataupun yang lainnya.

Perdukunan menyebar keseluruh masyarakat Jawa baik di kalangan abangan, santri maupun priyai. Tetapi kebanyakan dukun ada pada kalangan abangan sehingga pandangan bahwa dukun abangan lebih banyak sedangkan dukun santri dan priyai lebih sedikit. Menjadi dukun dianggap berbahaya karena jika secara spiritual ia tidak kuat maka kekuatan yang luar biasa tersebut akan menghancurkannya. Bahkan orang yang mencoba menjadi dukun dengan berbagai cara namun gagal ia bisa menjadi gila. Namun berbeda bagi seseorang yang beruntung mewarisi kekuatan yang luar biasa 
tersebut. Meskipun kemampuan menjadi dukun sebagian adalah diwarisi namun kemampuan yang sebenarnya adalah dari belajar, sedangkan yang dipelajari antara dukun satu dengan lainnya berbeda. Dukun priyai cenderung menekankan pada aspek bertapa, puasa dan meditasi dalam waktu yang lama. Mereka menganggap bahwa kekuatan seluruhnya adalah spiritual. Dukun santri biasanya menggunakan ayat-ayat alQuran yang ditafsirkan secara mistik atau menggunakan potongan-potongan dari tulisan Arab yang ditulis dengan hati-hati yang bersifat magis untuk dikunyah dan ditelan. Dukun dari kalangan santri juga menganggap bahwa pengobatan yang dilakukan muslim sejati harus didasarkan pada pengetahuan medis yang terdapat dalam al-Quran. Sedangkan dukun abangan menitikberatkan pada jimat, mantra, tumbuhtumbuhan, ramuan obat dan lainnya (Geertz, 1983).

Dukun abangan yang jumlahnya lebih banyak dibanding dengan dukun santri dan priyai ini juga dipengaruhi oleh masih melekatnya tradisi atau budaya masyarakat zaman dahulu tentang jimat, jampi-jampi dan sebagainya. Banyak orang yang berusaha menjadi dukun namun tidak mampu, sehingga orang tersebut menjadi gila. Oleh sebab itu, menjadi dukun penuh dengan konsekuensi yang tinggi. Meskipun dukun abangan menggunakan jimat, mantra dan lainnya, masyarakat banyak yang mendatanginya. Ketenaran dukun abangan tidak kalah dengan dukun santri dan priyai, di mana masyarakat desa percaya pada dukun golongan apa saja yang terpenting adalah tujuannya yang berhasil. Para dukun mendapatkan prewangan bukanlah dari belajar, tetapi diwarisi oleh ayahnya. Ayahnya mencari ilmu dengan konsekuensi yang berat yaitu mengalami gila selama 7 kali setiap 7 tahunnya. Sebagaimana yang diungkapkan Mbah Jamiatun sebagai berikut:

"Ceritanya mbahmu ketika dahulu masih hidup mulai mengikuti di sini itu cerita. Raden Sahid Demak anaknya kan Sunan Muria itu pergi ke sana, keguguran dua bulan ibunya tidak tahu. Kemudian bapak saya melakukan, yang dilakukan dari aku bayi sampai gila selama tujuh kali. Orang-orang bilang ayahku gila kok. Ayahku sampai tua mati seperti gila tujuh kali. Tujuh tahun kambuh tujuh tahun kambuh. Itu tidak mengikuti ayahku. Lha aku anaknya yang besar itu ikut sama saya. Anaknya laki-laki dua aku yang pertama perempuan. Jadi seperti itu aku tidak tahu nak. Kamu tanya apa ya aku tidak tahu. Ada apapun tanya apapun tetap tidak tahu. Gila ilmu, mengaji, tidak pernah makan. Ayah saya kalu gilanya kambuh mengaji siang 
malam, sembahyang, berpenampilan seperti wanita seperti itu. Setelah itu sembuh. Sembuh kalau sudah ada tujuh tahun kambuh lagi. Tujuh kali itu. Memang dari aku bayi sampai tua baru meninggal kok. Sejarahnya seperti itu."

Kedudukan sosial dukun dalam masyarakat memiliki citra yang positif atau lebih baik. Biasanya citra positif ini banyak diwakili oleh dukun yang berorientasi pada santri. Citra yang melekat pada seorang dukun akan membuat dirinya dikenal masyarakat. Biasanya masyarakat yang secara geografis rumahnya terletak lebih jauh dengan dukun tersebut malah lebih mendengar atas ketenarannya. Bahkan masyarakat yang letak rumahnya dekat dengan dukun tersebut menganggapnya biasa-biasa saja (Saputra, 2007, hal. 293). Tidak semua dukun yang ada pada suatu desa dikenal dan didatangi warga sekitarnya. Malahan biasanya orang-orang dari luar desa atau daerah lain yang banyak datang pada dukun tersebut. Tidak heran dengan hal ini, karena memang banyak terjadi di masyarakat, yang mengistilahkannya dengan orak cocok, yang berarti bahwa tidak cocok atau tidak sembuh dengan pengobatan dukun di desa tersebut bahkan bisa cocok dengan berobat pada dukun di desa yang lain meskipun menggunakan cara yang sama.

Suku Jawa sebelum kedatangan agama Hindu telah menganut keyakinan animisme dan dinamisme sebagai akar spiritualnya. Keyakinan tersebut cukup mengakar sehingga dapat bertahan walaupun mendapat pengaruh dan berhadapan dengan kebudayaan yang telah berkembang maju. Menurut JWM. Bakker dalam Sofwan (2004, hal. 17-20) tentang kajian yang berjudul "Agama Asli Indonesia", walaupun sebagian besar orang Indonesia mengaku beragama Islam, sikap keagamaan yang mereka jaga dan lakukan dengan baik tidak ingin diubah oleh agama asing. Ciri khas keyakinan animisme-dinamisme adalah menganut kepercayaan roh-roh dan dayadaya gaib yang bersifat aktif. Prinsip roh aktif artinya kepercayaan animisme mengajarkan bahwa roh-roh orang mati tetap hidup dan bahkan menjadi sakti seperti dewa, dapat mencelakakan atau sebaliknya, membantu menyelamatkan dan menyejahterakan manusia. Di dunia ini juga dihuni oleh berbagai macam roh gaib yang bisa membantu atau mengganggu kehidupan manusia di dunia. Sehingga ritus atau upacara meditasi keyakinan animisme-dinamisme adalah untuk berhubungan dan mempengaruhi roh-roh dan kekuatan gaib tersebut, bahkan dengan jalan meditasi atau 
dukun prewangan adalah menjalin hubungan langsung untuk meminta bantuan dengan roh-roh dan kekuatan gaib.

Kata prewangan berasal dari bahasa Jawa yaitu rewang yang artinya kawan atau sahabat, sehingga prewangan berarti persahabatan. Dukun prewangan yang dimaksud di sini adalah orang yang melakukan praktek perdukunan atau orang yang mempunyai kepandaian menebak sesuatu dengan cara mendapatkan bantuan dari roh halus. Roh halus tersebut bisa dari rohnya orang yang telah meninggal atau setan (Hasyim, 1984, hal. 110).

Dukun prewangan yang ada di Desa Ngelokulon adalah Mbah Jamiatun. Praktek ini dimulai sejak tahun 70an sampai sekarang. Beliau banyak didatangi warga untuk dimintai bantuan. Prewangannya sendiri bernama Raden Ayu yang menurutnya berasal dari Muria. Ada hari-hari terttentu di mana Mbah Jamiatun tidak dapat melayani pasien. Oleh karena itu, pasien harus mengetahui hari praktek Mbah Jamiatun. Prewangan berarti dukun yang kerasukan jin atau makhluk halus, di mana jin ini biasanya dijadikan pelayan atau khodam. Jin sendiri adalah makhluk yang berbentuk roh dan berakal, diberi beban sebagaimana manusia dan alam. Secara hakikat bentuk jin tidak dapat diketahui. Jin pada mulanya diciptakan dari api yang tidak berasap dan jin diciptakan lebih awal dari manusia. Jin mempunyai beberapa golongan, yaitu pertama bersikap baik, dan mengerjakan kebaikan. Kedua, bersikap buruk dan mengerjakan keburukan. Ketiga, bodoh dan lengah. Dan keempat, kafir, jin ini adalah yang paling mayoritas (Sabiq, 1996, hal. 139-140).

Kesurupan dan prewangan itu berbeda. Kesurupan merupakan kemasukan roh atau makhluk halus tanpa disengaja. Orang yang kesurupan biasanya tidak sadarkan diri. Tanda-tandanya mirip orang stress dan suaranya berubah. Sedangkan prewangan adalah sebutan untuk dukun yang dalam prakteknya menggunakan jasa (rewang) roh atau makhluk halus masuk dalam dirinya dan dukun akan berbicara berdasarkan bisikan dari roh yang merasukinya. Tanda-tandanya adalah dukun tetap sadar, suaranya tidak berubah, kepala dukun akan tertunduk pada saat prewangan memasuki dirinya dan kepala dukun akan bergerak ke belakang (tengadah) pada saat roh prewangannya keluar dari tubuh si dukun. Apabila kesadaran dukun prewangan sama sekali tidak 
berperan, kadang suara dukun dan tingkah lakunya akan berubah sesuai roh yang masuk dalam dirinya (Masruri, 1997, hal. 97). Dukun prewangan yang peneliti temui memiliki ciri yang hampir sama dengan ciri-ciri yang disebutkan di atas, yaitu kesadaran dukun menghilang atau dukun tidak sadar apa yang telah ia katakan saat dirasuki prewangannya saat mengobati pasien dan suara maupun tingkah lakunya sedikit berubah. Suara dan logat bicaranya menjadi cadal dan seperti anak kecil.

Dukun prewangan yang semakin berkembang ini diklasifikasi menjadi dukun putih dan hitam. Dukun putih adalah seseorang yang menggunakan atribut Islami namun mempraktikkan amalan perdukunan, baik dukun tersebut menyadarinya atau tidak. Sedangkan dukun hitam adalah dukun yang melakukan praktek keburukan seperti santet untuk menyakiti atau membunuh, pelet, gendam dan sebagainya (AlRaaqiy, 2011, hal. 291-297). Dukun prewangan yang peneliti observasi dapat diklasifikasikan ke dalam dukun putih, karena dukun prewangan di sini biasanya membantu masyarakat dalam suatu pengobatan, kendati dalam praktiknya dukun ini tidak menggunakan atribut Islami.

Dukun juga diklasifikasikan menjadi tiga, yaitu pertama, dukun yang menguasai jin. Dukun ini telah melakukan ritual-ritual tertentu untuk mengundang bantuan jin. Ia merasa telah menguasai jin namun sebenarnya tidak, karena jin tidak akan membantu seseorang tanpa imbalan. Kedua, dukun yang dikuasai jin. Dukun ini didatangi jin untuk menawarkan bantuan kepadanya, terkadang tidak ada ritual khusus yang dilakukan. Jin biasanya datang melalui bisikan, kesurupan atau lewat benda tertentu serta dengan menampakkan diri dalam wujud tertentu. Ketiga, dukun palsu. Dukun ini mengandalkan intrik, tipu daya atau pengamatan dan pengalaman harian. Dukun ini dikatakan palsu karena jauh dari nuansa klenik atau mistik, tidak ada kekuatan gaib yang dimilikinya bahkan kadang mereka menggunakan trik khusus yang dipadu dengan teknologi dan cairan tertentu dalam aksinya. Menurut Umar Hasyim (Hasyim, 1984), ada berbagai macam cara dukun memanggil roh untuk memasuki tubuhnya yaitu dengan dukun mempersiapkan dirinya, membaca mantera-mantera dan syarat-syarat lainnya. Ketika suara ataupun perilaku dukun nampak berubah, berarti roh telah datang karena dipanggil oleh dukun. Dan roh tersebut masuk ke dalam tubuh dukun. Adapula dukun yang selamanya dimasuki roh orang yang telah meninggal tersebut. 
Sehingga kapan saja dan di mana saja dukun siap menjawab pertanyaan dan permohonan dari orang yang memerlukan jasa dukun tersebut.

Ketika jin merasuki tubuh manusia, jin berbicara dengan lisan manusia tersebut. Menurut Ibnu Taimiyah, keterangan tersebut merupakan perkataan mayoritas ulama yang terkenal. Jin merasuki jiwa manusia, kemudian manusia tersebut mengucapkan sesuatu yang ia sendiri tidak memahami maksudnya. Namun dalam berdialog dengan jin, manusia harus memperhatikan beberapa hal. Pertama, tidak boleh bertanya tentang masalah yang ghaib. Kedua, tidak mudah percaya dan membenarkan perkataan jin. Ketiga, boleh berdialog dengan jin yang merasuki tubuh manusia apabila mampu membedakan antara yang haq dan yang batil. Terkadang syaithan mengaku sebagai arwah atau kerabat tertentu, padahal hal tersebut dusta karena bertentangan dengan pandangan akidah Islam tentang ruh manusia setelah kematiannya (Al-Raaqiy, 2011).

Manusia yang percaya dengan tipu daya jin, karena manusia sangat mudah ditipu. Cara setan atau jin menggoda manusia, pertama, dengan menakut-nakuti manusia. Memperlihatkan diri sebagai hantu, memedi seperti gendruwo, kuntilanak dan lain-lain. Agar manusia mempercayai dunia gaib ruh halus, dengan begitu manusia akan takut dan mengakibatkan runtuhnya iman mereka karena banyak manusia yang tergelincir dalam kesyirikan. Kedua, yaitu dengan cara nyurup atau menjadi prewangan. Ketika orang kesurupan ruh halus, ia akan jatuh sakit dan berbicara tidak menentu. Ruh tersebut akan berkata bahwa ia mau pergi jika diberi hadiah berupa syarat-syarat yang tidak seberapa namun dapat membuat syirik seseorang. Ketiga, mengelabuhi mata manusia agar semakin tebal keimanannya kepada dunia gaib serta keajaiban yang dapat menjerumuskan pada syirik. Misalnya manusia diberi petunjuk menemukan bendabenda pusaka. Keempat, yaitu dengan jalan setan masuk ke ulu hati manusia dan masuk ke dalam aliran darah (Hasyim, 1984).

\section{Dasar Ramalan Perdukunan}

Dasar ramalan perdukunan (kahanah) adalah jin mencuri sebagian dari pembicaraan para malaikat, lalu ia menyampaikannya pada telinga kahin (dukun ramal). Pada zaman jahiliyah, ramalan perdukunan sangat tersebar di Arab. Ramalan yang mereka peroleh dari jin yang menuju ke arah langit dengan cara sebagian mereka 
menaiki sebagian yang lain hingga mereka mendekati bagian tertinggi yaitu tempat di mana dapat didengar perkataan para malaikat. Perkataan itu lalu disampaikan kepada jin yang ada di bawahnya sampai akhirnya diterima oleh jin yang menyampaikan ke telinga dukun ramal dengan berbagai tambahan. Ketika Islam datang, al-Qur'an turun dan langit dijaga dari setan dan dilemparkan kepada mereka suluh api (bintang) yang berkilat. Karena itu, setan hanya dapat mencuri apa yang dapat disambar oleh jin yang tertinggi, lalu disampaikan kepada yang ada di bawahnya sebelum terkena suluh api yang berkilat (Qardhawy, 1998). Mbah Jamiatun mendapat informasi dari prewangannya yang bernama Raden Ayu. Dari sinilah dukun mendapatkan informasi atas penyebab penyakit atau masalah pasien.

\section{Tipe dan Ciri Dukun}

Dalam prespektif hukum Islam, Macam-macam dukun yang diungkapkan Geertz jika dikaitkan dengan hukum Islam, terdapat dua tipologi dukun, yaitu dukun yang dibolehkan dan dukun yang diharamkan. Adapun dukun yang dibolehkan diantaranya adalah dukun bayi, dukun calak (tukang sunat), dukun rajah (tabib yang mengobati dengan menggunakan tanaman sebagai obat). Dalam istilah Geertz biasanya disebut dukun jampi. Adapun dukun yang diharamkan adalah dukun prewangan, dukun wiwit, dukun temanten, dukun ramal, dukun sihir, dukun susuk, dukun tiban, dukun kebatinan (menggunakan mistik untuk mencari kekebalan), dukun pijat, dukun kejuruan (ahli hikmah dari kalangan santri) (Hsubky, 1999, hal. 100-101). Praktek Mbah Jamiatun yang dibantu Raden Ayu termasuk kategori dukun yang diharamkan karena menggunakan bantuan jin.

Ciri-ciri perdukunan harus kita ketahui. Pertama, biasanya dukun bertanya nama, ayah dan ibu pasien untuk dibacakan mantera. Kedua, dukun juga menanyakan hari kelahiran, pasaran dan waktu kelahirannya, misalnya Senin Kliwon pagi, siang, sore ataupun malam. Ketiga, meminta barang atau benda pasien sebagai syarat melakukan ritual. Misalnya foto, baju dan sebagainya. Keempat, meminta binatang atau tanaman tertentu bahkan sesuatu yang lainnya, misalnya ayam cemani, bunga kantil, tanah kuburan, tanah dari rumah pasien, selametan dan lain sebagainya. Kelima, menulis jimat atau rajah, menggambar segi empat yang biasanya di dalamnya ditulis huruf dan 
angka. Memberikan benda pusaka, kain dan lain sebagainya. Keenam, membaca mantera yang tidak dipahami, potongan ayat al-Quran yang dipisah-pisah, membaca simbol-simbol tertentu sebagai pengganti mantera agar diamalkan pasien dengan cara dan hitungan tertentu. Ketujuh, menulis ayat al-Quran dari arah kiri atau menggunakan darah atau sesuatu yang najis lainnya. Padahal ayat-ayat al-Quran seharusnya dimulyakan, ditulis dengan baik karena ayat-ayat al-Quran adalah sebagai penyembuh. Kedelapan, pasien biasanya disuruh menyepi agar tidak terkena sinar matahari. Sembilan, pasien juga dilarang untuk tidak menyentuh air pada saat tertentu bahkan kadang disuruh mandi tengah malam.

Sepuluh, memberikan sesuatu yang harus ditempel di atas pintu, ditanam di bawah tanah ataupun dipakai pasien. Sebelas, menyuruh pasien beribadah dan melakukan wirid yang bid'ah. Contohnya puasa mutih, bertapa atau meditasi dan lainlain. Dua belas, kadang dukun mengetahui nama pasien atau jin yang ada dalam tubuh pasien tanpa pasien memberitahukan terlebih dahulu. Mempunyai kamar yang khusus dan tidak boleh dimasuki orang lain. Adanya pantangan untuk dukun dan pasien pada hari dan tanggal tertentu. Biasanya dukun mempunyai wajah yang suram, membakar kemenyan dan sulit untuk tawadhu. Tathayyur yaitu menghubung-hubungkan peristiwa atau fenomena alam dengan nasib baik ataupun buruk seseorang. Misalnya seseorang yang memiliki nasib sial karena mempunyai rumah tepat di pertigaan yang biasanya disebut rumah sate (Akhmad, 2006, hal. 9-10).

\section{Praktek Pengobatan Dukun Prewangan di Desa Ngelokulon}

Mbah Jamiatun menyatakan tidak menyadari apa yang beliau lakukan ketika mengobati, seperti pernyataannya sebagai berikut.

"Aku ya seperti orang tidur. Kalau ikut aku, aku seperti tidur tidak tahu apaapa. Ada orang berobat apa aku tidak tahu kok, kalau selesai ya pergi. Pertama kalinya Raden Ayu ikut aku itu dua tahun tidak pernah makan nasi kok. Tinggal tulang, waktu kecil. Zaman dahulu kok tinggal tulang. Dua tahun tidak pernah makan nasi kok sampai badanku habis kurus. Dari tahun 70 sampai sekarang. Sudah berapa tahun? Dari anakku masih kecil-kecil sampai anakku menikah semuanya, habis. Misalkan kamu tanya apa-apa aku tidak tahu. Memang kalau ikut aku, aku tidak tahu, orang yang melakukan bapak saya. Bapak saya sudah tidak ada kan ikut aku. Aku ya tidak tahu. Ada orang 
tanya apa aku itu tidak tahu apa-apa. Kalau terbangun ya biasa seperti ini. Ya sudah apakah tidak sadar itu seperti orang tidur. Sadar, tidak sadar itu seperti orang tidur. Perasaanku mata saya mengantuk mau tidur kalau ada tamu, seperti itu."

Pernyataan Bapak Solikhul tentang proses pengobatan Mbah Jamiatun sebagai berikut.

"Kakiku terkilir, saya pijatkan ke sana sampai dua kali hingga lebih baik dan akhirnya dapat berjalan lancar. Ketika mengobati, ia kesurupan dan berbaring di atas kasur. Kemudian dipijat dan diberi bobok yang terbuat dari beras dan garam sampai dua kali sehingga sembuh sampai sekarang."

Ada lagi pasien yang menjelaskan bagaimana pengobatan Mbah Jamiatun dalam pernyataannya.

"Tahu. Sudah beberapa kali kalau anak saya panas. Kadang ya aku kalau ada keluhan apakah itu tangannya terkilir atau apa. Biasanya diperlihatkan kalau tangannya sakit kemudian dikasih tahu tangan yang sakit kemudian dipijat. Jika terkilir ya diperbaiki, dipijat pelan-pelan oleh Mbah Jamiatun. Kalau anaknya panas ya disentuh anaknya, keningnya disentuh, biasanya ya kesambet di jalan. Jika kesawan orang meninggal ya bilang kalau ini kesawan orang yang meninggal sudah berapa hari begitu ya bilang orangnya. Misalkan jika kesambet ya diberi sawanan tetapi racikan tidak yang bubuk, diracik orangnya kemudian disuruh untuk dioleskan. Biasanya jika kesambet disuruh nambahi tanah trocohan depan rumah tiga cakupan. Bawang merah dipotongpotong 3, kemudian garam tiga cakupan dan diberi kertas coret-coretan dari mbah dukun. Biasanya jika diberi coret-coretan itu ditanyakan nama anaknya yang panas. Misalkan siapa namanya contohnya Husna ya ditulis. Tetapi tulisannya tidak Husna bentuknya hanya tadi coret-coretan jadinya, kalau kita yang melihat. Disuruh merendam air hangat kemudian disuruh meminumkan anaknya tadi. Kalau boboknya disuruh mengoleskan dari ubunubun, telinga, perut, tangan dan kaki. Sawanan racikan ya ada seperti kunyit diiris-iris, ada akar apa itu saya tidak tahu kalau orang tua-tua ya paham. Seperti ada hitam-hitam bentunya seperti jinten namun tidak tahu apa namanya. Ada bunga mawar juga, bunga gading yang ada di guwakan sawah seperti itu."

\section{Kecenderungan Masyarakat Desa Ngelokulon Pergi ke Dukun}

Masyarakat desa Ngelokulon memiliki kecenderungan datang ke dukun karena beberapa hal. Pertama, awamnya pengetahuan masyarakat tentang pengertian dukun, 
sihir dan ruqyah syar'iyyah. Kedua, adanya seseorang yang menamakan diri mereka kyai dan ulama tetapi pada kenyataannya mempraktikkan sihir dan perdukunan. Ketiga, lemahnya iman. Keempat, ajaran sufisme sesat. Kelima, adanya keyakinan animisme, dinamisme, sinkretisme. Keenam, tuntutan kehidupan materialisme modern (Akhmad, 2006).

Faktor-faktor yang melatarbelakangi masyarakat Desa Ngelokulon berobat pada dukun prewangan adalah pertama, keadaan demografi yang cukup dekat menjadikan masyarakat datang dengan mudah. Kedua, pengalaman seseorang yang kemudian tersebar dari satu orang ke orang lain. Ketiga, biaya pengobatan yang relatif murah dengan kesembuhan yang didapat menjadikan masyarakat memilih berobat pada dukun. Keempat, kurangnya pengetahuan masyarakat tentang pengobatan yang sesuai syariat Islam. Kelima, rasa penasaran dan ingin mencoba atas informasi dan pengalaman orang lain. Seorang pasien mempunyai alasan khusus ketika berobat pada dukun yaitu cara memijatnya yang tidak terlalu sakit. Jika dipijat orang lain, cara memijatnya keras sehingga pasien merasa kesakitan. Mbah Jamiatun bukan hanya menangani masalah pengobatan saja, keluhan barang yang hilang juga dapat diketahui. Biasanya barang yang ditanyakan ketemu setelah diramal oleh Mbah Jamiatun berada di mana. Namun pasien harus tahu bahwa ada hari-hari tertentu di mana Mbah Jamiatun tidak dapat mengobati pasien karena prewangannya pergi.

\section{Pergi Ke Dukun Dalam Prespektif Hukum Islam}

Hukum berobat ke dukun sebagaimana Rasulullah telah bersabda,

"Bukanlah dari golongan kami, seorang yang menggunakan petunjuk setan atau burung dan sebagainya, atau praktik sihir untuk menerka nasib, jodoh, penyakit dan obatnya. Maka, barangsiapa mendatangi seorang dukun yang melakukan praktik-praktik demikian lalu ia percaya akan keterangannya, orang ini adalah orang yang telah mendustakan, dan tidak percaya dengan apa-apa yang diwahyukan kepada Muhamamd saw."

Biasanya para dukun dalam mengobati pasiennya menggunakan jampi-jampi atau bacaan-bacaan yang kadang tidak dimengerti oleh pasien. Para ulama mengatakan bahwa bacaan pengobatan atau jampi-jampi yang diperbolehkan syariah harus memenuhi tiga syarat. Pertama, menyebut nama Allah. Kedua, menggunakan bahasa 
Arab atau bahasa lainnya yang dapat dipahami maknanya. Ketiga, keyakinan bahwa jampi-jampi tidak berpengaruh kecuali dengan takdir Allah dan tidak menjerumuskan kepada syirik. Meskipun jampi-jampi yang dibaca tidak dimengerti pasiennya, baik segi lafalnya, maknanya maupun tulisannya, pasien tetap mempercayai dan menggunakan apa yang diberikan dukun (Utomo, 2003, hal. 235-236). Begitu juga dengan apa yang dilakukan Mbah Jamiatun, apa yang beliau bacakan pada pasien tidak dapat didengar dan dipahami dengan baik.

Mengenai orang yang datang ke dukun, Nabi Muhammad saw. bersabda, yang artinya.

"Barang siapa mendatangi peramal, lalu bertanya kepadanya dan membenarkan apa yang dikatakannya, maka tidak diterima shalatnya selama empat puluh hari." (HR. Muslim).

"Barang siapa mendatangi dukun lalu membenarkan apa yang dikatakannya, ia telah mengingkari wahyu yang diturunkan kepada Muhammad." (Qardhawi, 2007, hal. 336)

Sebagai umat Islam yang baik kita harus menjalankan apa yang ada dalam alQuran dan hadis dalam urusan pergi ke dukun. Karena aturan dibuat pasti mempunyai tujuan dan kebaikan di dalamnya.

\section{Tinjauan Akidah Islamiyah Terhadap Kepercayaan Masyarakat Pada Pengobatan Dukun Prewangan Di Desa Ngelokulon}

Secara etimologi kata "akidah" berarti "terikat", maksudnya adalah perjanjian yang teguh dan kuat, tertanam di dalam lubuk hati yang paling dalam. Ahli bahasa menyebutkan kata akidah berasal dari kata aqada, ya'qadu, aqdan, aqidatan yang berarti ikatan, perjanjian, dan kokoh. Istilah akidah sering disebut tauhid. Istilah tauhid berasal dari bahasa Arab yang berarti mengesakan Allah. Hasan Al-Bana dalam Gunawan (Gunawan, 2015, hal. 151-155) menyebutkan bahwa akidah sebagai sesuatu yang seharusnya hati membenarkannya, sehingga menjadi ketenangan jiwa yang menjadikan kepercayaan bersih dari berbagai keraguan dan kebimbangan. Akidah Islamiyah berfungsi dan berperan dalam kehidupan. Pertama, memperkuat keyakinan dan mempertebal kepercayaan atas kebenaran ajaran Islam sehingga tidak ada keraguan 
dalam hati. Kedua, menuntun dan mengembangkan dasar ketuhanan yang ada sejak lahir. Ketiga, memberi ketenangan dan ketentraman jiwa. Keempat, memberikan pedoman hidup yang pasti. Kelima, menjaga diri dari kemusyrikan.

Masyarakat memiliki persepsi dan pendapat beragam dalam melihat fenomena dukun prewangan di Desa Ngelokulon. Salah seorang tokoh agama Desa Ngelokulon melarang masyarakat mempercayai prewangan seperti pernyataannya berikut:

"Kalau prewangan itu ya seperti ini ya, sebenarnya itu kembali pada orang yang dukun itu sendiri. Kepercayaan itu, tapi rata-rata masyarakat awam dukunnya prewangan memang prewangan itu. Kalau percaya pada prewangan itu memang tidak baik, menyimpang dari akidah. Itu kalau saya tergantung dari masyarakat yang datang ke sana. Itu anggapannya bagaimana. Saya ibaratkan seperti ini, mau panen dahulu itu wiwit di sawah. Lha itu, saya ibaratkan seperti itu. Jadi selametan di sawah itu orang zaman dahulu kepercayaannya dia itu apa yang meniaga padi Mbok Sri atau Dewi Sri. Kalau percaya pada itu kan salah, selametan ya salah. Sekarang sudah diarahkan, selametan di sawah ataupun di rumah silahkan, tapi kita memohon selamat kepada Allah berdoa kepada Allah dan sebagainya tidak apa-apa. Itu kalau saya arahkan ke sana itu seperti itu. Tapi condongnya memang banyak yang salah. Masyarakat soalnya percaya pada prewangan itu. Kalau menurut saya sih sebaiknya tanya ya jangan yang seperti itu misalkan sakit atau apa, datang ke seorang ulama setidak-tidaknya dibacakan fatihah mungkin bisa menjadi obat itu juga fatihah. Jadi mohon kepada Allah."

Seorang akademisi membolehkan adanya dukun prewangan yang membantu warga.

"Tapi cuma masalahnya seperti ini. Dia melakukan itu kok bisa seperti itu metodenya bagaimana. Ilmu yang diperoleh itu melalui apa kira-kira? Jadi datangnya prewangan tadi yang membantu dia itu bukan diperoleh dengan jalan-jalan yang tidak baik? Soalnya begini, ada orang yang bisa berkomunikasi dengan makhluk-makhluk halus dengan melanggar syariat. Misalnya harus menginjak al-Quran supaya nanti prewangannya datang. Kalau semacam itu sudah barang tentu nanti ya tidak diperbolehkan. Tetapi kalau apa tadi mewarisi? Kalau mewarisi jika dia bisa berkomunikasi tidak melakukan hal-hal yang menyimpang ya itu ya tidak apa-apa. Soalnya apa itu kan terkait dengan mistik ya. Ada mistik hitam ada mistik putih. Orang bisa mempunyai kemampuan-kemampuan yang sifatnya gaib ya kalau itu nanti bisa untuk mencelakakan orang lain ya terus kemudian caranya untuk bisa memperoleh itu dengan cara yang tidak baik dengan cara menginjak al-Quran misalnya itu mistik hitam. Kalau mistik hitam itu jelas dalam pandangan akidah Islam itu tidak dibenarkan. Tapi kalau mistik putih ya. Itu kan nanti 
seorang yang bisa mempunyai mistik putih itu nanti kan untuk kemanfaatan orang ya. Biasanya cara untuk memperoleh itu bukan dengan jalan yang dilarang oleh syariat. Tapi mungkin dia bisa memperoleh ilmu kayak itu mungkin dengan jalan riyadhoh dengan amalan-amalan ibadah, kalau semacam itu kan tentunya nanti kan hasilnya untuk kemanfaatan. Itu bolehboleh saja. Kalau itu dikatakan sebagai mistik putih."

Akademisi lain melarang praktek dukun, alangkah lebih baik dengan doa sebagai obatnya. Seperti pernyataannya berikut ini:

"Jane ono tambahane ciri indikator dukun itu apa. Indikator dukun itu. Pertama, seseorang yang menggunakan sesuatu yang tidak sesuai atau menggunakan media yang tidak sesuai syariat Islam justru menjauh dari Gusti Allah. Menggunakan prewangan apa itu jin jarak jauh. Itu kan yang nggak boleh. Kalau kamu mengatakan itu boleh jangan mengatakan itu dukun. Lhah ngono lho maksute. Orang yang kamu anggap dukun kalo itu selama tidak menyimpang syariat Islam, jangan kamu katakan dukun. Kalau dia menyimpang syariat islam maka baru dukun. Saya cuma menyarankan ini kan cuma teori. Saya menyarankan, pertama pakai doa, kedua yang mengamalkan dia sendiri. Kita ikut mendoakan. Lho ojo misalkan awake dewe seng maen dia tidur, jangan. Logis tidak? Jadi intinya dukun itu tidak boleh. Intinya satu cari makna dukun. Kira-kira makna dukun itu positif tah negatif? Wes reti ngono re. Kalau itu negatif kenapa kok boleh? Lho yo po rak? Logikanya seperti itu ndak? Makanya saya tidak boleh apapun bentuknya. Ini yang harus kamu waspadai. Ndak boleh, wes pokoe kalau sudah menamakan orang ndak boleh, haram. Nak ngobatine boleh, nek nolong kan boleh. Nek muni mendapatkan ini dari Sunan Muria itu nggak boleh. Ngono maksute. Dia menolong orang baik. Itu yang nggak boleh. Lha mulane to itu namanya ikhtilat. Campur antara haq dan batil. Dia ngobati apek tah orak? Lhayo ngobati apik, tapi dia mengatasnamakan dari Sunan Muria. Itu yang tidak boleh. Wakeh wong seng ngono iku. Prewangan jangan, sebaik-baik jin sejahat-jahat manusia, jin itu kecil."

Sebagai umat Islam yang baik, seharusnya kita mengaplikasikan rukun iman dan segala yang diatur oleh Allah SWT. Warga Desa Ngelokulon meyakini atas kuasa Allah SWT., namun dalam berobat mereka mendatangi dukun prewangan. Hal ini adalah tidak sesuai dengan ajaran akidah Islamiyah, karena Islam tidak mengajarkan manusia mempercayai apa yang dikatakan dukun dan ramalannya. Iman tidak hanya diucapkan dan diyakini dalam hati saja, namun aplikasi dari keimanan tersebut harus dilakukan karena ketiganya saling berkaitan. 


\section{Simpulan}

Kecenderungan masyarakat pada pengobatan dukun prewangan di Desa Ngelokulon disebabkan faktor geografi, faktor popularitas sang dukun serta minimnya pengetahuan masyarakat tentang pengobatan yang sesuai syariat Islam. Tinjauan akidah Islamiyah terhadap kepercayaan masyarakat pada pengobatan dukun prewangan adalah haram atau tidak diperbolehkan. Sesuai hadis nabi bahwa orang yang percaya pada apa yang dikatakan dukun berarti tidak mempercayai apa yang diwahyukan Allah SWT. pada Nabi Muhammad Saw. Bahkan shalatnya orang yang bertanya dan membenarkan perkataan dukun tidak akan diterima selama 40 hari lamanya. 


\section{Referensi}

Akhmad, P. (2006). Membongkar Kesesatan Perilaku Syirik Masyarakat Indonesia Perilaku Mistik Pada Masyarakat Ahli Syirik di Indonesia. Sukabumi: Quranic Healing Indonesia (Didukung: Adamssein Media).

Al-Raaqiy, I. R. (2011). Menyingkap Jin dan Dukun Hitam-Putih Indonesia. Surabaya: Halim Jaya.

Amir, J. H. dan A. (2009). Etika Kedokteran dan Hukum Kesehatan Edisi 4. Jakarta: EGC.

Artaria, A. S. dan M. D. (2016). Pemilihan penyembuhan penyakit melalui pengobatan tradisional non medis atau medis Choosing the type of healing method. Masyarakat, Kebudayaan dan Politik, 29(1).

Ash-Shiddiqiey, T. M. H. (2009). Sejarah dan Pengantar Ilmu Tauhid/Kalam. Semarang: Pustaka Rizki Putra.

Geertz, C. (1983). Abangan, Santri, Priyai Dalam Masyarakat Jawa. Jakarta Pusat: Pustaka Jaya.

Gunawan, D. A. G. dan H. (2015). Studi Islam Suatu Pengantar Dengan Pendekatan Interdisipliner. Bandung: PT. Remaja Rosda Karya.

Hasyim, U. (1984). Memburu Wangsit dan Suara Dari Kubur. Surabaya: Bina Ilmu.

Hsubky, B. (1999). Bid'ah-Bid'ah di Indonesia. Jakarta: Gema Insani.

Masruri, D. S. dan. (1997). Dialog Seputar Kekuatan Gaib. Solo: Aneka.

Melalatoa, M. J. (1995). Ensiklopedi Suku Bangsa di Indonesia jilid L-Z. Departemen Pendidikan dan Kebudayaan RI.

Prawirohardjo, R. S. (1978). Kedokteran Jiwa dan Perdukunan. Berkala Ilmu Kedokteran (Journal of the Medical Sciences), X(3).

Qardhawi, Y. (2007). Halal Haram Dalam Islam. Solo: Era Intermedia.

Qardhawy, Y. (1998). Wangsit Kasyaf Mimpi Perdukunan dan Pengobatan Spiritual Dalam Tinjauan Islam. Jakarta: Robbani Press.

Sabiq, S. (1996). Akidah Islam Suatu Kajian Yang Memposisikan Akal Sebagai Mitra Wahyu. Surabaya: Al Ikhlas.

Saputra, H. (2007). Memuja Mantra dan Jaran Goyang Masyarakat Suku Using Banyuwangi. Yogyakarta: LKIS. 
Sayuti, A. R. (2013). Tradisi Pengobatan di Dapur Ditinjau Dari Akidah Islam (Studi Kasus di Desa Ukui Dua Kecamatan Ukui Kabupaten Pelalawan-Riau). Universitas Islam Negeri Sultan Syarif Kasim.

Sofwan, R. (2004). Merumuskan Kembali Interelasi Islam-Jawa. Yogyakarta: Gama Media.

Sujarwa. (1999). Manusia dan Fenomena Budaya Menuju Perspektif Moralitas Agama. Yogyakarta: Pustaka Pelajar.

Utomo, S. B. (2003). Fiqih Aktual Jawaban Tuntas Masalah Kontemporer. Jakarta: Gema Insani Press. 